\title{
EVALUATION OF POLICY IMPLEMENTATION 2018 VISIT YEAR AS AN EFFORT TO IMPROVE THE ECONOMIC INDEPENDENCE OF THE COMMUNITY IN SUMENEP REGENCY
}

\author{
Wilda Rasaili, Nur Inna Alfiyah \\ Lecturer State Administration, Wiraraja University Sumenep \\ wilda@wiraraja.ac.id,nurinna@wiraraja.ac.id
}

\begin{abstract}
This study aims to evaluate the implementation of visit year 2018 policy as a way to developed regional tourism and increase regional economic independence. The program of visit year 2018 started to be planned as policy featured local of Sumenep government since 2016. The policy as the program featured to develop a variety of tourism potential of the region, such as marine tourism, health tourism, tourism keris, culture and palace. But in fact, the increase in the economy of Sumenep district from 2016-2018 was quite slow, the increase was only 0,20 percent, the lowest compared to other districts in East Java. This condition is related to the ineffective implementation of the 2018 visit year policy. Good policies without effective implementation, policies will not be success (Akib and Tarigan, 2008). Policy implementation needs to get more attention, because policies will not find expectations if the implementation is not optimal (Pulzl and Treib. 2014: 127). This study uses a qualitative descriptive method. This study explained that the policy implementation of the visit year 2018 was not effective. 4 (four) indicators of policy implementation as in Edward III's theory, and the environmental aspects of implementation proposed by Nakamura and Smallwood (1980), not running optimally, 1) human resources are not optimally prepared, and development is slow, 2) coordination and communication between actors in tourism development is still weak, 3) The dispositions didn't work systematically organized, 4) The aspects of bureaucratic structure still occur over lapping between each OPD .The study recommends that need to be did developing human resources, the coordination and effective communicate between actors in the policy, and the disposition clearly, especially in the OPD.
\end{abstract}

Keywords: Evaluation, policy implementation, visit year 2018, economic independence.

\section{Introduction}

This research explain about the evaluation implementation of policy program in the visit year 2018 as government strategy in improve society economy and area in the district sumenep with introduce and maximizing tourism potency. The policy of visit year 2018 as a priority program Sumenep government contained in the RPJMD in 2016-2021 (transmadura.com.2017). all organization regional devices (OPD) are pushed for together support the success of visit year 2018 so the the program objectives are achieved maximum. The purpose of the program that in improve growth economy good independent in urban areas or rural area.

For some decade, tourism sector has been experience growth and has been strengthen its role in economy. Tourism has been change to be a real industry that produces income annual exceed 1,3 billion \$ and create more of 260 million job (Sandu. 2014). Tourism sector as wrong one industry demands that can push up growth economy society and area (Karim. 2010). According to Kreag (2001), tourism impact has three aspect; economic, social and culture, and empowerment. But generally and 
formally impact tourisme on a planning facilities economy society in creating a tourism industry. Tourism more impact on growth economy society if managed and implemented in a manner effective and strategic.

In a few area in Indonesia, tourism sector to be priority development and policy for support progress area. Policy in the tourism sector many give away evidence success in each area. For example, development tourism in the district Banyuwangi and the impact on enhancement economy society and area. Tourism as activities economy because move displacement from something area other area with aim certain. So, the tourism have role important in context development local economy. Public institutions must realized capacity and potency tourism area for managed and developed as area development (Pedrana. 2013)

Distict of Sumenep have and interest for make the tourism sector as superior and strategic in improve society economy. The development of tourism been planned sice early 2016 second period government Busro-Fauzi, and make a visit year 2018 as the good program government area. In developing visit year 2018 the government have done some repair and development tourism facilities and transportation for tour. Besides that, there are 36 tourism event that area prepared for introduce potency tour and push power pull traveler visit to Sumenep.

Although some area pour out his attention on tourism sector policy but that in secessary noticed on premise of implementation. Nugroho (2014:2013-214) said that success public policy determined by implementation policy with a percentage of $60 \%$ while $20 \%$ comes from good planning or formulation, and $20 \%$ is determined from the implementation control. The position of implementation or in his language Barret (2004) is "translating policy into action" gets more attention, because policy does not seem to meet policy expectations if it is not translated well in action (Pulzl and Treib. 2014: 127). Then the implementation concept is very strategic in the success of the policy. Policies will not have meaning if they are not implemented, so that implementation policy becomes an important complement of policies made to achieve policy objectives. Edward III (1984) states, without effective implementation the decision of policy will not be successful (Akib and Tarigan, 2008).

Then, in this research, the researcher use implementation concept as base reference research for evaluate the visit year 2018 program in implementation aspect. In concept policy implementation there are some indicators are important to consider for effective implementation. In the concept Edward III (1980) which gives attention to four main issues for the successful implementation of policies,between; communication, resources, attitude disposition, and bureaucratic structure. Communication indicator also clarify by Goddin and Lester (1990), that as generator from some implementation variables of policy (Nugroho, 2015:219-229). Besides author using environmental model indicators that influence policy implementation. Nakamura and Smallwood (1980) said that there are elements with actors evenly on each environment is, environmental policy formulation and policy implementation . 


\section{Research method}

The research method that is descriptive of qualitative. Descriptive research is research that describe and explain problem from accur situation (Moeleng, 2014:11). Qualitative research method is method for explore and understand meaning that by a number of individual or group of people considered originated from social problems or humanity (Creswell, 2013:4-5). The research process qualitative that will used efforts; file questions and procedures, specific collecting data from participant, analyze data and interpret the meaning of the data (Creswell, 2013:6)

\section{Visit Years 2018 Policy}

The program visit year 2018 is superior program of the Sumenep regency government to supported the increase people's economy to interest tourist attraction by introducing various tourism potentials in Sumenep. The program vist year has been planned and has become a study since the beginning of 2016 and continues to be prepared by several OPD to go to of 2018 year. The government officially launches the Sumene calendar of event (CoE) visit year 2018 on Tuesday, December 2017 at the Hall of Soesilo Soedarman, Sapta Pesona Building Jakarta , Ministry of Tourism (Kumparan.com .2018). Regency Government to the theme 'Interesting and Healthy ' by maximizing some tourism potential including; nature tourism, religious tourism, cultural tourism, historical tourism, artificial tourism, special interest tours, geo tourism, culinary tourism and healty tourism by making Giliyang Island (oxygen island) an icon.

Begin the program visit year 2018, by introducing various excellent potentials of Sumenep, the government intends to increase the total of visiting and tourist who come. Because the tourism sector is a strategic sector that can be managed to increase regional progress, especially in increasing the economy. In the ame manner in international agenda that tourism is the commercial sector are also planned and recommended by the World travel \& Tourism Council (WTTC) Word Tourism Organization (WTO) and the Earth Council (EC) to be developed by States on an ongoing basis, because The tourism sector has a broad impact on the economy, social, industry, environment and society (Aall, 2014) .

Begin to policy visit year 2018 , the government targets there are a significant increase in the total of visitors. In 2018 year the government is targeting 1,1 million tourists, which is twice that of previous years. There are the increase in tourists, the government also believes that there is an increase in local revenue (PAD) and an increase in the economy of the community (Duta.com, 2018). Sector tourism is a strategic activity that encourages high entrepreneurship, increased investment, and as a new era of regional economic development. Tourism accesses new shares from activities, popularization and their implications for improving the economy and resources (Rukuižienè). The program Visit years 2018 as a regional government policy that aims to support the increasing in the total of tourist with the promotion and development of tourism potential in Sumenep. There are encouraging increase of 
tourist visiting, it can be expected to have implications for increasing to support economy of community by attention the potential superior local economic (Karim, 2018 in an Jakarta Newspaper interview) .

For supporting the achievement objectives of the visit year 2018 program the government have done steps and efforts between .

1. Development of tourism potential in Sumenep, by completing infrastructure tourism and facilities in tourism environments.

2. There are supporting of each OPD, as well as the integration of cooperation and support from external parties such as; media, entrepreneurs, academics, tourists and the community (Sumenepkab.go.id . 2017) .

3. Providing enough infrastructure and transportation. Availability of street lighting for tourism, land, sea and air transportation. The government also cooperates with Sumekar Line to provide Speed Boat from Kalianget port to Giliyang Island. Transportation and infrastructure improvements as tourism development programs to encourage attraction and facilitate tourists (newssatu.com. 2017)

4. Providing tourism promotions by tourist events. In the 2018 the government prepares 36 events with local, provincial, national, regional and international. Some of the events featured for 2018 include Gathering media and business communities of Tourism in Indonesia, Pupils festival in Indonesia, Cat countest of International, Fishing festival of International, the palace festival and Indigenous ASEAN V who attended from the palace throughout the archipelago and ASEAN (visitsumenep .com . 2017)

\section{Increasing Community Economy and PAD}

In 2011 there are research conducted by Nur (2011), showed that Sumenep district was included in the criteria for high income but low growth economic growth. The advance region but depressed, namely regions that have higher per capita income, but have lower economic growth rates. In 2009 Sumenep per capita GRDP reached 4,686,794, 3 while GRDP growth was 4.24 lower than in other regions in Madura (Nur, 2011). This analysis does not include the tourism sector which has a significant influence on economic growth. Stretching tourism as a sector that contributes to economic growth starting in 2012 and in 2013 the tourism sector is targeted to contribute $30 \%$ of PAD (sumenepkab.go.id.2013). In 2014 the government targeted Rp.230 million, in 2015 it was targeted at Rp.264 million, in 2016 it was targeted at 280 million, in 2017 it was targeted at Rp232 million, in 2018 the government promoted the target by 15 percent, Rp. 370 million (mediamadura.com . 2018). Since the early era of regent A Busro Karim, the tourism sector has also become a target in increasing economic growth and PAD. Sector tourism as one of the industry demands that can support community economic growth and PAD (Karim, 2010). 
Focusing on 2017-2018 as the target of achieving community economic growth and increasing PAD which is supported by the visit year 2018 program, it will be explained in two parts.

1. Increased PAD. In 2018 the 6 th month the tourism sector has reached $71 \%$ of those targeted by the government. So that until the end of 2018 the government believes that PAD from the tourism sector reaches even more targets (limadetik.com.2018). The achievement of the target was greatly helped by the 2018 visit year program because in previous years the tourism sector had always not reached its target. But the community and the DPRD argued that the target set by the government was too small. The government only raised the target of 15\% at 2017 besides in 2018 was the realization of the 2018 visit year program with a budget reaching 4 billion. The government should have raised the level of achievement.

2. Community economic improvement. In this aspect, the visit year 2018 program still does not have a significant impact on improving the economy of the community, both the tourism environment and the general sumenep community.

Based on the results of interviews conducted on three community groups, namely hotel voters, traveling services, and culinary services, indicating that the existence of a visit year program was not too influential on improving the community's economy even the same as in previous years. Chairul Gafar, owners Musdalifah hotel, say that the majority who stay in hotels because of their business, office and work opportunities are not tourism visits, there is no difference between tourist events with increased income for hotel owners. The same thing was said by Ramdhan, as the manager of traveling services (Kencana Tour and Travel), that the increase in tourists since the declaration of the tourist event program was not too significant, even some tourists who came to Sumenep gave a less attractive impression regarding facilities, access and transportation. While the results of interviews with culinary entrepreneurs show there is an economic improvement from tourism events. But the increase was only during the implementation of events such as the ketupat festival on the lombang beach witj on ordinary days just the same as in previous years.

The policy of visit year 2018 which aims to achieve economic independence by introducing tourism potentials in Sumenep has still not been maximally achieved. The economic growth and community income levels are not too significant although the government has programmed a visit Sumenep. The data shown are specifically related directly to the impact of tourism such as hospitality, traveling and culinary in the tourism environment. Not to mention the economic growth general society in Sumenep. Bakorwi East Java, said that economic growth in Sumenep district was still low, the increase was only 0,2 percent (koranmadura.com, 2018).

The objectives of visit year 2018 program can't be optimally analyzed from the aspect of policy implementation. There is an in-depth evaluation regarding the 
implementation of the visit year 2018. The visit program is a superior program nationally and in various regions because it can support economic growth. Banyuwangi Regency is one example of the success of a visit because it has raised economic growth. How good programs and policies are but not accompanied by effective implementation, policy objectives are difficult to achieve. So, from that the evaluation of the implementation of the visit year 2018 needs to be done to find the problem of not achieving the goals of community economic growth.

\section{Evaluation of Visit Year 2018 Implementation}

In the concept of policy implementation there are several important indicators to be observed so that implementation is effective. In the concept Edward III (1980) which gives attention to four main issues for the successful implementation of policies, between; communication, resources, attitude disposition, and bureaucratic structure . Indicator also be clear communication, that communication as a generator of some variabel policy implementation. In addition, the authors include also indicators of environmental models that influence policy implementation. That there are three elements with actors that are evenly distributed in each environment namely, the environment of policy formulation and policy implementation .

Policy Implementation evaluation refers to how the look indicators in the concept of implementation can be considered by the government in the success of the visit year 2018 program in order to achieve the goal. Then some of the evaluations that are emphasized in this paper include.

1. Resource readiness. In this case the concern of the author is human resources. Human resources that is competent in tourism development is quite minimal in the possession of the local government, in addition to the integration of cooperation with universities that have the resources to do it to the maximum. As a result of the weakness of human resources in the visit year 2018 program, there are some shortage that find, for example the absence of tourism agenda mapping and tourism promotion, and events that were widely criticized by the public at Asean palace festivals, public criticism of the al batik festival because be in contradiction witht local wisdom, and the arrangement of the environment facility that does not give the impression of tourism interest. Generally of the weak human resources who have a role in the Sumenep visit year program, it was suggested that the program was not ready. This was proven to have led to a reaction in the form of demonstrations carried out by the Extra-Parliamentary Student Movement (Gempar) to the regent's office and tourism and sports agency, which claimed that the visit year 2018 program was not ready and the purpose was unclear.

2. Communication pattern. Local governments often explained in several public forums that the success of the visit year 2018 is determined by external roles which include the community, entrepreneurs, media and academics. The government's position is recognized only as a facilitator and 
mobilizer. However the government have a key role in communication patterns with each actor. This communication aspect is weakly carried out by the government with external parties. Deputy chairman of the Indonesian Journalists Association (PWI), Ibn Hajar said that the government was not ready to communicate with the media so that the media tended to provide tourism without clear direction, in addition he also said that communication was not built with entrepreneurs, both investors and culinary entrepreneurs, it is evidenced by tourism that is not developing significantly different from tourism managed by the private sector.

3. The attitude of the bureaucracy or the executor does not really give a room to the public in absorbing the aspirations and ideas in succession visit year 2018 program. The actors that seen as supporting the development of tourism potential and visit year 2018 was not much involved in the planning and the fraction in the implementation. The researchers looked at four actors namely the media, investors, academics and the public. From interviews conducted each actor states not involved in planning the visit year 2018 program. international event of mania mancing that hold on in Giliyang island involve groups of society (community groups) in the conduct but the concept and planning people are not involved. Then in the case of the festivals of the palace and the indigenous peoples of Asean, the media besides not being involved in planning there was also no communication about how the targets and objectives to be achieved by the government through media promotion. As stated by Hokiyanto, the journalist Limadetik, said that the media was not invited to communicate by the government both pre and post the event. So the news that appears in the media is because it's worth the news.

4. The program of visit year 2018 as specific are in the department accountable culture, tourism, youth and sport (Disbudparpora). But the government is encouraging the integration of cooperation and support each OPD to success for visit year 2018. However, the bureaucratic work often overlap for a succession program visit year. As the results of an interview with the head of the Transportation Agency that,

"... in Sumenep there is transportation" odong-odong "which triggers the attraction of tourists to climb, odong-odong is a modification of the community that originates from an open threewheeled vehicle which is prohibited from carrying people. But because it is modified to be a vehicle that has a throne pattern, a flying horse, and so on, becomes a unique and interesting vehicle. But the operation is illegal, so in this case there needs to be a clear work flow from dinsbudparpora, dishub, and the police. But it is still unclear (Sumenep, 12 - 10- 2018) ".

In other case, for example, the management of lombang beach tourism consists of government, investors and local communities. Communities and investors manage fully on 2 major days in 1 year, Ketupat and New Year. Submitted management fully proves that bureaucratic work is not ready. Investors and the public need to be 
invited to collaborate to advance and manage tourism not submit with a tender system.

5. Implementation environment. The people of Sumenep generally still have not fully embraced the development of tourism which support tourist attraction. Public attitudes related to religious fanaticism, wisdom local and travel impressions by bringing different cultures which is feared to erode cultures local. The community environment is not managed properly by the government by first giving massive socialization and orientation visits that can benefit the community.

\section{Conclusion}

The implementation of the policy and visit year 2018 program in increasing the economic independence of the community developing of tourism potentials have several weaknesses and shortage. The achievement of the level of economic growth is still weak and the community consisting of hotel owners, traveling and surrounding communities is not too sensitive to feel the economic impact of the visit year 2018. The economic impact to the surrounding community is merely incidental on the momentum of the implementation of tourist events with a duration of 1-2 days, after which it returns as previous days. The significance of the visit year 2018 program when evaluated in the implementation concept contained 5 aspects of the problem. 1) weak human resources are owned either by the government or outside the cooperative, 2) the lack of coordination and communication between actor in success of the visit year 2018.especially Disbudparpora as a leading sector and actor to build coordination and good communication environment OPD as well as with external actors, 3) there are not well-organized working attitude for OPD with employers, the media, academia and the public, 4) the Aspects of the bureaucratic structure still occur over lapping between each OPD, and 5) the implementation environment or society not fully providing support for increasing tourists and investment. The presence of tourists still feared will crush local culture and strong values relegius in Sumenep society.

This research also recommends that the necessary must do improvement of human resources, especially in the environment associated with the competence development of tourism. The government also engages intensity with outside actors who have the ability in tourism. Then as the implementing government as well as the leading sector. So, the coordination and communication need to be intensified with outside actors such as entrepreneurs, the community, academics and the media. Each actor is not only involved in technique but communicated in ideas and planning, it is needed. 


\section{References}

Aall Carlo. (2014). Sustainable Tourism in Practice: Promoting or Perverting the Quest for a Sustainable Development?. Journal. Sustainability 2014, 6, 2562-2583; doi:10.3390/su6052562

Akib Haedar dan Antonius tarigan. (2008). Artikulasi Konsep Implementasi Kebijakan: Perspektif, Model dan Kriteria Pengukurannya. Journal. Jurnal Baca, Volume 1 Agustus 2008, Universitas Pababari Makassar.

Cresweel John W. (2013). Research Design, Pendekatan Kualitatif, Kuantitatif dan Mixed. Yogyakarta: Pustaka Pelajar.

Karim Abuya Busro. (2010). Pariwisata; antara Tuntutan Industri dan Kearifan Lokal". Journal. KARSA, Vol. XVIII No. 2 Oktober 2010

Kreag Glenn . (2001). The Impacts of Tourism. Minnesota Sea Grant 2305 E Fifth Street. www.seagrant.umn.edu

Moeleng, Lexy. (2004). Metode penelitian kualitatif". Edisi revisi. Bandung, PT. Remaja Rosdakarya.

Nugroho Riant. (2015). Kebijakan Publik di Negara-negara Berkembang., Yogyakarta: Pustaka Pelajar.

Nur Azmi Faiz, Ida Nuraini. (2011). Analisis Potensi Ekonomi Sektoral pada Empat Kabupaten di Pulau Madura". Journal. Jurnal Ekonomi Pembangunan, Vol 9 No. 1 Juli 2011.

Pedrana Margherita. (2013). Local economic development policies and tourism. An approach to sustainability and culture. Journal. Regional Science Inquiry Journal, Vol. V, (1), 2013, pp. 91-99

Pulzl Helga dan Oliver Treib. (2014). Public policy implementation. edisi terjemahan., Bandung: Nusa Media

Rukuižienè Rasa. Sustainable Tourism Development Implications to Local Economy". Journal. Regional FoRmation and development StudieS, no. 3 (14) http:/ /dx.doi.org/10.15181/rfds.v14i3.873

Sandu Elena. (2014). Comparative Study on the Management of Sustainable Touristic Development in Brasov and Brussels Counties. Journal. Journal of tourism studies and research in tourism [Issue 18]. http:/ / revistadeturism.ro/rdt/article/view/278

Gafar, Chairul. (2018, Oktober 25). Personal interview 
Hajar Ibn (2018, Oktober 03) Personal Interview.

Hokiyanto. (2018, Okotober 02) Personal Interview

Ramadhan. (2018, Oktober 28). Personal Interview

\section{Newspaper Website}

http://www.transmadura.com/2017/04/08/perencanaan-visit-2017-sudah-selesaisopd-satukan-persepsi-2018-sudah-aksi/.

https://kumparan.com/mediamadura/resmi-dilaunching-ini-deretan-even-sumenepvisit-year-2018

https://duta.co/menuju-visit-sumenep-year-2018-1/

http://www.koran-jakarta.com/pariwisata-potensi-ekonomi-unggulan-sumenep/

http://sumenepkab.go.id/berita/baca/visit-sumenep-years-2018-harus-didukungfaktor-eksternal

https:// newssatu.com/sumenep/ berita-sumenep/sambut-visit-2018-ini-persiapanpemkab-sumenep/

https://visitsumenep.com/sumenep-luncurkan-kalender-wisata-2018/

http:// sumenepkab.go.id/berita/baca/wisata-sumenep-ditarget-sumbang-pad-naik30-persen

https://mediamadura.com/2018/07/26/pad-sektor-pariwisata-di-sumenep-ditargetterlalu-kecil/

https:/ /limadetik.com/enam-bulan-terakhir-disparbudpora-sumenep-klaim-padsektor-wisata-capai-70-persen/

http://www.koranmadura.com/2018/03/pertumbuhan-ekonomi-sumenep-rendah/

http://www.transmadura.com/2017/04/08/perencanaan-visit-2017-sudah-selesaisopd-satukan-persepsi-2018-sudah-aksi/ 